\title{
Analisis SWOT PT. ASDP Indonesia Ferry (Persero) Pelabuhan Ketapang-Gilimanuk
}

\author{
Erlina Lestari ${ }^{*}$, Kadek Rai Suwena ${ }^{2}$ \\ 1,2 Universitas Pendidikan Ganesha, Singaraja - Indonesia
}

\section{A R T I C L EI N F 0}

Article history:

Received January, 52021

Received in revised form

November, 242021

Accepted November, 26

2021

Available online December, 252021

\section{Kata Kunci:}

Analisis SWOT, kualita

pelayanan, PT. ASDP.

Keywords:

PT. ASDP, service quality,

SWOT analysis.

\begin{abstract}
A B S T R A K
Tujuan dari penelitian ini adalah untuk menganalisis kekuatan (Strength), kelemahan (Weakness), peluang (Opportunities) dan ancaman (Threats) dengan menggunakan analisis SWOT pada kualitas pelayanan jasa PT. ASDP Indonesia ferry (persero) pelabuhan Ketapang-Gilimanuk. Penelitian ini menggunakan jenis penelitian dengan metode penelitian deskriptif yaitu mendeskripsikan mengenai kualitas pelayanan jasa PT. ASDP Indonesia Ferry (persero) Pelabuhan Ketapang-Gilimanuk. Populasi dalam penelitian ini yaitu pengguna jasa yang menggunakan jasa layanan PT. ASDP dengan sampel yang digunakan sebanyak 384 responden yang diperoleh dengan menggunakan teknik accidental sampling. Data dikumpulkan dengan observasi, kuesioner dan dokumentasi dan dianalisis dengan menggunakan analisis deskriptif kuantitatif. Hasil penelitian yang didapat dari menyusun analisis matriks SWOT berdasarkan IFAS yaitu total skor faktor kekuatan dikurangi dengan total skor faktor kelemahan dari kualitas pelayanan jasa PT. ASDP Pelabuhan Ketapang-Gilimanuk didapatkan hasil 1,5. Sedangkan berdasarkan EFAS skor peluang dikurangi dengan skor faktor ancaman didapatkan hasil 2,25.
\end{abstract}

\section{A B S T R A C T}

The purpose of this study is to analyze the strengths (strengths), weaknesses (weaknesses), opportunities (opportunities) and threats (Threats) using a SWOT analysis on the quality of services of PT. ASDP Indonesia ferry (persero) Ketapang-Gilimanuk port. This study uses this type of research with descriptive research methods that describe the quality of services PT. ASDP Indonesia Ferry (Persero) Ketapang-Gilimanuk Port. The population in this study are service users who use the services of PT. ASDP with the sample used as many as 384 respondents obtained using accidental sampling technique. Data were collected by observation, questionnaires and documentation and analyzed using quantitative descriptive analysis. The results obtained from compiling a SWOT matrix analysis based on IFAS, namely the total score of the strength factor minus the total score of the weakness factors of the service quality of PT. ASDP Ketapang-Gilimanuk Port obtained 1.5 results. Meanwhile, based on EFAS, the opportunity score is reduced by the threat factor score, the result is 2.25 .

\footnotetext{
* Corresponding author.

E-mail : erlinalestari2017@gmail.com (Erlina Lestari)
} 


\section{Pendahuluan}

Untuk meningkatkan daya saing, perusahaan harus menetapkan metode SWOT untuk menghadapi persaingan pasar terutama menghadapi pasar global. Analisis SWOT merupakan pemahaman faktor secara sistematis untuk merancang rencana perusahaan. Berdasarkan timbal balik faktor internal dan faktor eksternal (Freddy Rangkuti, 2005:18). Menurut (Sedarmayanti, 2018) penjelasan dari SWOT yaitu : Strenghts (sumber daya keterampilan dan keunggulan yang berbeda dengan pesaing dan dibutuhkan oleh banyak orang), Weaknesses (kelemahan pada perusahaan yang dapat menghambat kinerja perusahaan), Opportunities (peluang yang dapat menguntungkan bagi perusahaan), Threats (keadaan yang membahayakan lingkungan perusahaan).

Perusahaan harus menaruh perhatian pada pemeliharaan keunggulan bersaing melalui produk pelayanan yang baik untuk menghadapi persaingan domestik dan global, maka perusahaan perlu menyesuaikan SWOT dengan target market dan memanfaatkan kelemahan target tersebut menjadi sebuah peluang dalam hal kualitas pelayanan. Pentingnya menganalisis SWOT pada perusahaan yaitu sebagai langkah penentu masa depan dalam berjalannya sebuah bisnis, tentang cara sebuah perusahaan menjalankan strategi untuk mencapai tujuan yang diinginkan. Perusahaan yang memiliki target market yang baik harus menyesuaikan analisis SWOT pada perusahaannya untuk mencapai tujuan visi perusahaan, seperti Perusahaan Terbatas Angkutan Sungai Danau Penyeberangan yang memberikan pelayanan dalam bidang jasa penyeberangan untuk penumpang, kendaraan, dan barang. Parasuraman et al., dalam Fandy Tjiptono (2014:268) terdapat 5 Dimensi utama sebagai penentu suatu pelayanan jasa sebagai berikut. (1) Reliability (Keandalan) yaitu keakuratan perusahan dalam memberikan pelayanan sesuai dengan batas waktu yang telah ditentukan. (2) Responsiveness (Daya Tanggap) yaitu kemampuan untuk membantu para pelanggan dan merespon permintaan mereka dengan menyediakan pelayanan yang cepat dan tepat. (3) Assurance (Jaminan) ialah sebuah sikap menumbuhkan rasa percaya kepada perusahaan terhadap berbagai macam keadaan. (4) Empathy (Empati) ialah memberi rasa perhatian terhadap kebutuhan dari pelanggan. (5) Tangible (Bukti langsung) yang meliputi sarana dan prasarana serta material tertulis yang digunakan perusahaan.

Objek penelitian yang diambil oleh peneliti kali ini yaitu PT. ASDP Indonesia Ferry (Persero) Pelabuhan Ketapang-Gilimanuk, ada beberapa kebijakan-kebijakan yang dikeluarkan oleh perusahaan masih kurang efisien untuk dilaksanakan oleh pengguna jasa. Seperti kebijakan terbaru yaitu penerapan penggunaan tiket online yang salah satunya bertujuan untuk membagi distribusi kendaraan atau orang yang datang lebih merata dan sesuai dengan kuota pelabuhan, sehingga pengalaman macet terutama saat peak season dapat lebih terurai.

Menurut Fandy Tjiptono, (2014:353) "pelanggan merasakan puas/tidak puas setelah menggunakan produk atau pelayanan bersangkutan dengan menaruh harapan awal sebelum membeli dari produk tersebut". Perhatian terhadap pelayanan adalah salah satu upaya PT. ASDP Indonesia Ferry (Persero) Pelabuhan Ketapang-Gilimanuk dalam memberikan kepuasan terhadap pelanggan yang tentunya bertujuan untuk meningkatkan pencapaian visi dan misi dari perusahaan. Seiring dengan hal tersebut kualitas pelayanan jasa PT. ASDP Indonesia Ferry (Persero) Pelabuhan Ketapang-Gilimanuk tahap demi tahap telah melakukan perbaikan, terbatasnya kapal dan fasilitas dermaga, serta pelayanan pembelian tiket mendapat perhatian lebih dari PT. ASDP Indonesia Ferry.

Menurut (Hamali, 2016) "analisis SWOT adalah identifikasi yang bersifat sistematis dari faktor internal dan faktor eksternal yang memberikan perpaduan terbaik diantara faktor-faktornya. PT. ASDP Indonesia Ferry (Persero) Pelabuhan Ketapang-Gilimanuk tentu memiliki kekurangan dan juga kelebihan dalam mengembangkan dan menjalankan usahanya. Dengan menentukan penilaian SWOT perusahaan dapat melihat dalam menentukan hal yang diutamakan dalam kualitas pelayanan dan harus dibenahi terlebih dahulu oleh perusahaan baik itu dari segi kekuatan perusahaan yang harus dijaga dari segi kelemahan perusahaan tersebut yang harus dibenahi dari segi peluang yang akan terjadi kedepannya maupun dari segi ancaman yang akan terjadi.

\section{Metode}

Metode penelitian deskriptif dengan pendekatan kuantitatif merupakan metode penelitian yang penulis gunakan. Penelitian deskriptif merupakan metode yang mengilustrasikan masalah yang terjadi sekarang dan bertujuan untuk menguraikan hal yang terjadi ketika penelitian dilakukan (Arifin dan Zainal, 2011). Penelitian ini dilakukan untuk mendeskripsikan lingkungan internal dan eksternal pada PT. ASDP Indonesia Ferry (Persero) Pelabuhan Ketapang-Gilimanuk. Lokasi penelitian ini dilaksanakan di 
Pelabuhan Gilimanuk pada PT. ASDP Indonesia Ferry (Persero). Populasi yang digunakan ialah pengguna jasa kapal ferry yang jumlahnya tidak diketahui dan dapat dikatakan dalam kategori tidak terhingga. dengan sampel yang digunakan sebanyak 384 responden yang dicari menggunakan teknik accidental sampling.

Peneliti menggunakan data primer dalam bentuk observasi dan kuesioner sehingga dapat diperoleh jawaban secara langsung dari masing-masing responden serta data sekunder yang berupa dokumentasi dan catatan atau laporan historis. Peneliti menggunakan metode pengumpulan data dengan observasi dan kuesioner. Dimana kuesioner tersebut berisikan skala likert berjumlah 5 skor, dengan skor 1 merupakan kategori sangat tidak positif hingga skor 5 merupakan kategori sangat positif. Kuesioner diuji terlebih dahulu menggunakan uji valid dan relia menggunakan SPSS 20.0 for windows sebelum kuesioner disebarkan kepada responden. Instrumen kuesioner tersebut bisa dikatakan valid jika koefisien korelasi lebih besar dari $\mathrm{r}$ tabel dengan kesalahan alpha 0,05 . Sedangkan bisa dikatakan relia jika suatu variabel mampu atau memiliki nilai cronbanch'c alpha $>$ dari 0,60.

Penelitian ini menggunakan teknik analisis data SWOT analysis untuk mengidentifikasi kualitas pelayanan jasa PT. ASDP Indonesia Ferry (Persero) Pelabuhan Ketapang-Gilimanuk. Adapun langkahlangkah dalam analisis SWOT, yaitu. Analisis lingkungan internal digunakan dalam mengidentifikasi faktor kekuatan dan kelemahandari kualitas pelayanan jasa PT. ASDP. Kemudian menentukan analisis lingkungan eksternal digunakan untuk mengidentifikasi faktor peluang dan ancaman. Selanjutnya dilakukan matriks strategi analisisi SWOT yaitu perumusan terhadap strategi yang akan digunakan dan melihat posisi perusahaan berada pada kuadran disebelah mana.

\section{Hasil dan pembahasan}

Berdasarkan analisis lingkungan internal yang dilakukan untuk mengidentifikasi faktor strategis kekuatan dan kelernahan serta analisis lingkungan eksternal yang dilakukan dalam mengidentifikasi faktor strategis peluang dan ancaman di PT. ASDP Indonesia Ferry (Persero) Pelabuhan KetapangGilimanuk, maka didapatkan hasil dan pembahasan sebagai berikut.

Tabel 1. Analisis Lingkungan Internal Internal Strategic Factor Analysis Summary (IFAS)

\begin{tabular}{|c|c|c|c|c|}
\hline Faktor Strategis Internal & Bobot & Rating & Skor & Komentar \\
\hline \multicolumn{5}{|l|}{ Kekuatan (Strenght) } \\
\hline $\begin{array}{l}\text { 1. Fasilitas yang dimiliki kapal ferry lengkap dan } \\
\text { bersih. }\end{array}$ & 0,10 & 4 & 0,40 & \\
\hline $\begin{array}{l}\text { 2. Kebersihan lingkungan Pelabuhan terjaga dengan } \\
\text { baik. }\end{array}$ & 0,10 & 4 & 0,40 & \\
\hline $\begin{array}{l}\text { 3. Fasilitas yang ada di lingkungan Pelabuhan lengkap } \\
\text { dan dapat digunakan dengan baik. }\end{array}$ & 0,10 & 4 & 0,40 & \\
\hline $\begin{array}{l}\text { 4. Tempat parkir kendaraan yang disediakan sesuai } \\
\text { dengan kebutuhan pengguna jasa. }\end{array}$ & 0,05 & 4 & 0,20 & \\
\hline $\begin{array}{l}\text { 5. Petugas/pegawai yang bekerja di Pelabuhan } \\
\text { Gilimanuk bersikap sopan dalam memberikan } \\
\text { pelayanan. }\end{array}$ & 0,10 & 4 & 0,40 & \\
\hline $\begin{array}{l}\text { 6. Petugas/pegawai yang bekerja di Pelabuhan } \\
\text { Gilimanuk bekerja sesuai dengan standar prosedur } \\
\text { pelayanan yang telah ditetapkan. }\end{array}$ & 0,10 & 3 & 0,30 & \\
\hline $\begin{array}{l}\text { 7. Petugas/pegawai yang bekerja di Pelabuhan } \\
\text { Gilimanuk mampu memberikan pelayanan dengan } \\
\text { baik kepada pengguna jasa. }\end{array}$ & 0,10 & 4 & 0,40 & \\
\hline $\begin{array}{l}\text { 8. Petugas/pegawai yang bekerja di Pelabuhan } \\
\text { Gilimanuk mampu menangani keluhan jika terjadi } \\
\text { sesuatu yang tidak diinginkan oleh penggunaa jasa. }\end{array}$ & 0,05 & 4 & 0,20 & \\
\hline Jumlah & 0,70 & & 2,7 & \\
\hline \multicolumn{5}{|l|}{ Kelemahan (Weakness) } \\
\hline $\begin{array}{l}\text { 1. Kondisi toilet yang ada di dalam kapal maupun } \\
\text { pelabuhan kurang terjaga. }\end{array}$ & 0,10 & 4 & 0,40 & \\
\hline 2. Pegawai kurang cepat tanggap dalam memberi & 0,05 & 4 & 0,20 & \\
\hline
\end{tabular}


pelayanan.

3. Pegawai ada yang tidak jujur dan kurang $0,05 \quad 4 \quad 0,20$ bertanggung jawab.

4. Pegawai kurang dalam hal memberikan informasi $\quad 0,05 \quad 4 \quad 0,20$ yang jelas kepada pengguna jasa yang mengalami masalah.

5. Petugas/pegawai masih ada yang berbelit-belit $0,05 \quad 4 \quad 0,20$ ketika melayani pengguna jasa.

Jumlah

0,30
1,2

Jumlah bobot $=1,00$

Jumlah skor kekuatan-kelemahan $=1,5$

Tabel 2. Analisis Lingkungan Eksternal

Eksternal Strategic Factor Analysis Summary (EFAS)

\begin{tabular}{|c|c|c|c|c|}
\hline Faktor Strategis Internal & Bobot & Rating & Skor & Komentar \\
\hline \multicolumn{5}{|l|}{ Peluang (Opportunity) } \\
\hline $\begin{array}{l}\text { 1. PT. ASDP menjalankan standar operasional } \\
\text { pelayanan dengan baik dan tidak bertentangan } \\
\text { dengan aturan dan hukum. }\end{array}$ & 0,15 & 4 & 0,60 & \\
\hline $\begin{array}{l}\text { 2. Adanya kerjasama antara perusahaan, pemerintah, } \\
\text { dan masyarakat dalam mengembangkan pelayanan } \\
\text { PT. ASDP. }\end{array}$ & 0,15 & 4 & 0,60 & \\
\hline $\begin{array}{l}\text { 3. Keberadaan pelabuhan Ketapang-Gilimanuk } \\
\text { membuka lapangan pekerjaan bagi masyarakat } \\
\text { sekitar. }\end{array}$ & 0,10 & 4 & 0,40 & \\
\hline $\begin{array}{l}\text { 4. Keberadaan pelabuhan Ketapang-Gilimanuk } \\
\text { membuka lapangan pekerjaan bagi masyarakat } \\
\text { sekitar. }\end{array}$ & 0,10 & 4 & 0,40 & \\
\hline $\begin{array}{l}\text { 5. } \begin{array}{l}\text { Keberadaan pelabuhan } \\
\text { meningkatkan pendapatan bagi masyarakat } \\
\text { sekitar. }\end{array} \\
\text { malimanuk }\end{array}$ & 0,10 & 4 & 0,40 & \\
\hline $\begin{array}{l}\text { 5. Keberadaan pelabuhan Ketapang-Gilimanuk } \\
\text { memberikan keuntungan finansial bagi negara dan } \\
\text { masyarakat. }\end{array}$ & 0,10 & 4 & 0,40 & \\
\hline $\begin{array}{l}\text { 6. Kunjungan wisatawan asing dan domestik } \\
\text { berdampak positif kepada objek wisata yang } \\
\text { dikelola masyarakat. }\end{array}$ & 0,05 & 4 & 0,40 & \\
\hline $\begin{array}{l}\text { 7. PT. ASDP Pelabuhan Ketapang-Gilimanuk memiliki } \\
\text { fasilitas berbasis teknologi. }\end{array}$ & 0,10 & 4 & 0,40 & \\
\hline Jumlah & 0,75 & & 3,2 & \\
\hline \multicolumn{5}{|l|}{ Ancaman (Threat) } \\
\hline $\begin{array}{l}\text { 1. Ketersediaan informasi mengenai PT. ASDP belum } \\
\text { dapat dengan mudah dan cepat untuk didapatkan. }\end{array}$ & 0,05 & 3 & 0,15 & \\
\hline $\begin{array}{l}\text { 2. Ketersediaan informasi mengenai PT. ASDP belum } \\
\text { dapat dengan mudah diakses di internet. }\end{array}$ & 0,05 & 4 & 0,20 & \\
\hline $\begin{array}{l}\text { 3. Informasi mengenai PT. ASDP belum banyak } \\
\text { ditemukan di media sosial. }\end{array}$ & 0,10 & 4 & 0,40 & \\
\hline $\begin{array}{l}\text { 4. Terdapat alternatif layanan jasa lain yang menjadi } \\
\text { pesaing PT. ASDP. }\end{array}$ & 0,05 & 4 & 0,20 & \\
\hline Jumlah & 0,25 & & 0,95 & \\
\hline \multicolumn{5}{|l|}{ Jumlah bobot $=1,00$} \\
\hline Jumlah skor peluang- ancaman $=2,25$ & & & & \\
\hline
\end{tabular}

Keterangan :

Ukuran pembobotan.

Ukuran rating kekuatan \& kelemahan.

$0,00 \quad$ : Tidak Penting

$1=$ Sedikit kuat/lemah 


$$
\begin{array}{ll}
0,05 & \text { : Sedikit Penting } \\
0,10 & \text { : Cukup Penting } \\
0,15 & \text { : Penting } \\
0,20 & \text { : Sangat Penting }
\end{array}
$$

$$
\begin{aligned}
& 2=\text { Cukup kuat/lemah } \\
& 3=\text { Kuat/lemah } \\
& 4=\text { Sangat kuat/lemah }
\end{aligned}
$$

Berdasarkan dari hasil tabel 1 dan tabel 2 yaitu. IFAS diperoleh total skor untuk faktor kekuatan dari kualitas pelayanan jasa PT. ASDP Indonesia Ferry (Persero) Pelabuhan Ketapang-Gilimanuk sebesar 2,7 dikurangi dengan skor untuk faktor kelemahan sebesar 1,2 maka didapatkan sebesar 1,5. Sedangkan berdasarkan hasil dari EFAS diperoleh skor untuk peluang PT. ASDP Indonesia Ferry (Persero) adalah sebesar 3,2 dikurangi dengan total skor faktor ancaman sebesar 0,95 didapatkan hasil 2,25.

Berdasarkan dari kedua hasil perhitungan tersebut diperoleh hasil untuk lingkungan internal berada pada titik 1,5 dan untuk lingkungan eksternal berada pada titik kuadran 2,25. Hal tersebut menggambarkan bahwa matriks strategi SWOT kualitas pelayanan jasa PT. ASDP Indonesia Ferry (Persero) Pelabuhan Ketapang-Gilimanuk berada pada titik (1,5:2,25). Berdasarkan hasil tersebut, maka strategi yang tepat untuk diterapkan pada kualitas pelayanan jasa PT. ASDP Indonesia Ferry (Persero) Pelabuhan Ketapang-Gilimanuk dapat dilihat pada Gambar 1.

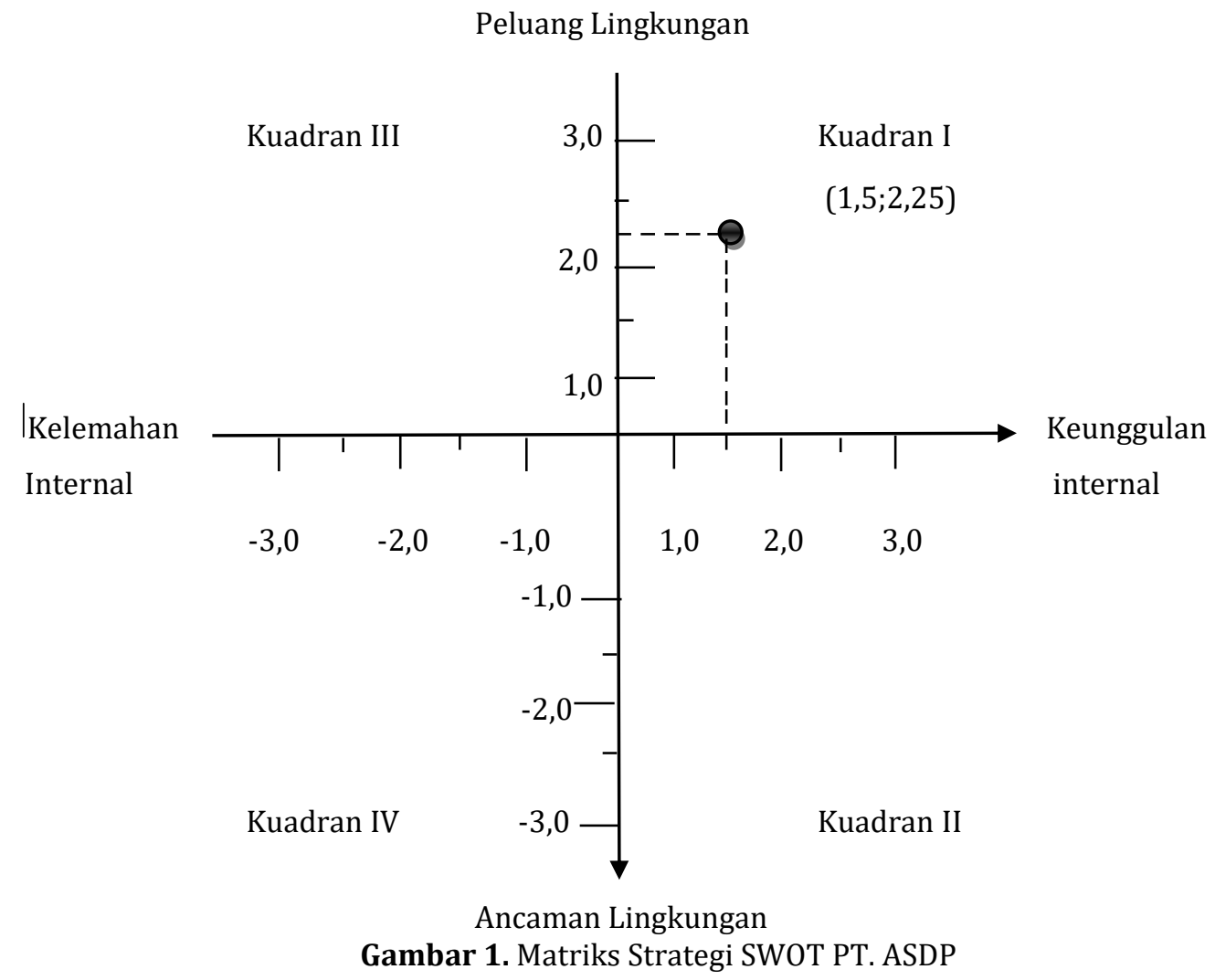

Pada gambar 1 dapat dilihat bahwa posisi pelayanan jasa PT. ASDP Indonesia Ferry (Persero) Pelabuhan Ketapang-Gilimanuk berada pada posisi kuadran I yaitu strategi pertumbuhan agresif. Salah satu dari strategi pertumbuhan agresif yang disarankan adalah strategi pengembangan produk, yang dijalankan dalam rangka memperbaiki atau memodifikasi produk yang dipasarkan kepada pengguna jasa melalui saluran pemasaran yang ada berfokus pada pengembangan pertumbuhan yang terkonsentrasi.

Maka strategi pengembangan produk terkait dengan PT. ASDP Indonesia Ferry (Persero) adalah dengan memfokuskan pengembangan kualitas pelayanan jasa dengan melakukan modifikasi terhadap produk berupa kapal-kapal ferry yang ada sekarang dalam hal ini adalah memberikan pelayanan yang prima kepada pengguna jasa atau penciptaan alternatif baru untuk meningkatkan pelayanan dan masih terkait dengan produk yang ada sekarang. Upaya yang dapat dilakukan adalah dengan melakukan peningkatan atau perbaikan fasilitas-fasilitas penunjang pelayanan yang ada di kapal maupun pelabuhan, meningkatkan kebersihan lingkungan terutama kebersihan toilet yang ada di dalam kapal, mempermudah proses pelayanan penjualan tiket, dan mensosialisasikan atau menyebarluaskan informasi terkait 
pelayanan PT. ASDP melalui internet dan sosial media serta menyebarluaskan informasi melalui media offline juga sangat diperlukan pada strategi ini.

Hasil penelitian yang diperoleh sejalan dengan pendapat (Assauri, 2013) "perusahaan berada pada kuadran I dilihat jika perusahaan memiliki kelebihan internal dengan peluang eksternal". Dengan demikian pilihan strategi yang disarankan pada kondisi yang mendukung pertumbuhan agresif adalah strategi pengembangan produk.

\section{Simpulan dan saran}

\section{a. Simpulan}

Hasil yang telah didapatkan serta pembahasan yang telah dipaparkan sebelumnya, Strategi yang tepat untuk digunakan sebagai pengembangan kualitas pelayanan jasa PT. ASDP Indonesia Ferry (Persero) Pelabuhan Ketapang-Gilimanuk adalah strategi pengembangan produk. Strategi pengembangan produk yaitu dengan memfokuskan pengembangan kualitas pelayanan jasa dengan melakukan modifikasi terhadap produk berupa kapal-kapal ferry yang ada sekarang dalam hal ini adalah memberikan pelayanan yang prima kepada pengguna jasa atau penciptaan alternatif baru untuk meningkatkan pelayanan dan masih terkait dengan produk yang ada sekarang. Upaya yang dapat dilakukan adalah dengan melakukan peningkatan atau perbaikan fasilitas-fasilitas penunjang pelayanan yang ada di kapal maupun pelabuhan, meningkatkan kebersihan lingkungan terutama kebersihan toilet yang ada di dalam kapal, mempermudah proses pelayanan penjualan tiket, dan mensosialisasikan atau menyebarluaskan informasi terkait pelayanan PT. ASDP melalui internet dan sosial media serta menyebarluaskan informasi melalui media offline juga sangat diperlukan pada strategi ini.

\section{b. Saran}

Berdasarkan hasil, pembahasan, dan simpulan yang telah dipaparkan sebelumnya, maka peneliti mengajukan beberapa saran yaitu Perusahaan hendaknya dapat memberikan pelayanan dengan maksimal kepada pengguna jasa dengan cara melengkapi sarana dan prasarana penunjang di kapal ferry maupun pelabuhan serta menjaga kebersihan lingkungan sekitarnya. Dengan adanya sarana dan prasarana serta kebersihan yang terjaga maka pengguna jasa akan merasa kebutuhannya terpenuhi sehingga merasa nyaman dengan pelayanan yang telah didapat. PT. ASDP pusat hendaknya lebih memperhatikan dan memberikan dukungan kepada pelabuhan-pelabuhan kecil yang berada dibawah naungannya seperti pelabuhan Ketapang-Gilimanuk, melalui sarana dan prasaranan, pelatihan dan pembinaan kepada petugas/pegawai serta menyebarluaskan informasi melalui media sosial agar pengguna jasa lebih mengetahui informasi terkini terkait penyeberangan dan info lainnya. Untuk dapat mewujudkan strategi pengembangan produk pihak perusahaan hendaknya memfokuskan pada pengembangan pelayanan yang membuat pengguna jasa nyaman ketika menggunakan jasa penyeberangan, serta penciptaan produk baru yang masih terkait dengan produk yang ada saat ini. Selain itu, perusahaan hendaknya memanfaatkan perkembangan teknologi dengan melakukan upaya promosi dan penyebaran informasi yang menarik melalui media sosial dan internet.

\section{Daftar Rujukan}

Abubakar, Barzach, \& Kenasin. 2013. Suatu Pengantar Pelayanan Perairan Daratan. Jakarta: Rajawali Press.

Arifin, Zainal. 2011. Penelitian Pendidikan: Metode dan Paradigma Baru. Bandung: PT. Remaja Rosdakarya Assauri, Sofian. 2013. Strategic Management Sustainable Competitive Advantanges. Jakarta: Rajawali Pers.

Ferry taufik hidayat Raningsih hardjo. 2014. Analisis SWOT dalam meningkatkan pelayanan program transjakarta: Universitas Indonesia

Firdaus AK. 2012. Tingkat kepuasan pengguna jasa dalam pelayanan studi kasus PT ASDP Indonesia Ferry di Pelabuhan Merak Banten. Banten: Uiversitas Sultan Ageng Tirtayasa.

Hamali, Arif Yusuf. 2016. Pemahaman Strategi Bisnis dan Kewirausahaan. Jakarta: Prenadamedia Group. Hardiansyah. 2011. Kualitas Pelayanan Publik. Yogyakarta: Gava Media.

Irawati R. 2012. Analisis swot pelabuhan ferry Sekupang Batam. Administrasi bisnis terapan Politeknik Negeri Batam. 1(1): 1-15.

Keputusan Direktur Jenderal Perhubungan Laut. Nomor: UM.002/38/18/DTML/11.

Kalaminudin Muhammad, 2013 Analisis Pelayanan Penumpang Kereta Api Prambanan Ekspres (Prameks) Trayek Jogjakarta - Solo 
Kinnear, Thomas C. And James R. Taylor.(1995).Marketing Research: An AppliedApproach. McGraw Hill Text.

Nugroho Eko. 2018. Prinsip-prinsip Menyusun Kuesioner. Malang: UB Press.

Oktavia DS. 2013. Perancangan Balanced Scorecard untuk pengembangan strategi di Seameo Biotrop. Bogor: Institut Pertanian Bogor.

Rangkuti, F. 2015. Analisis SWOT Teknik Membedah Kasus Bisnis. Jakarta: PT. Gramedia Pustaka Utama.

Rahmayanty, Nina.2013. Manajemen Pelayanan Prima.Yogyakarta: Graha Ilmu.

Riduwan dan Akdon. 2010. Rumus dan Data dalam Analisis Data Statistik. Bandung: Alfabeta.

Rusda Irawati, SE. MS.i, Benny Syahroni, ST., MM. 2015. Analisis SWOT Pelabuhan Ferry Internasional Sekupang: Politeknik Negeri Batam.

Sedarmayanti. 2018. Manajemen Strategi. Bandung: PT. Refika Aditama.

Siregar, Syofian. 2011. Statistika Deskriptif untuk Penelitian: Dilengkapi Perhitungan Manual dan Aplikasi SPSS Versi 17. Jakarta: PT. Rajagrafindo Persada

Solihin, dkk. 2019. Perumusan Strategi Jasa Angkutan Penyebrangan PT. ASDP Indonesia Ferry Lintas Bakauheni-Merak: Manajemen Bisnis Transportasi dan Logistik (JMBTL).

Sujana IM. 2013. Perancangan pengukuran kinerja pelabuhan penyeberangan dengan pendekatan balanced scorecard PT ASDP Indonesia Ferry (Persero) cabang Surabaya. Bandung: Institut Teknologi Bandung.

Sukmawati A. 2011. Model penciptaan pengetahuan untuk meningkatkan keunggulan bersaing koperasi susu di Indonesia. Bogor: Institut Pertanian Bogor.

Sunyoto Danang. 2012. Dasar-dasar Manajemen Pemasaran: Yogyakarta: CAPS

Syahroni B. 2012. Analisa SWOT dan penyusunan strategi pemasaran,pelabuhan, studi kasus pelabuhan feri Internasional Sekupang. Jakarta: Universitas Terbuka.

Tjiptono, Fandy. 2014. Pemasaran Jasa. Cetakan ke-4. Yogyakarta: C. V Andy Offset.

Tjiptono. Fandy dan Gregorius Chandra. 2011. Service Quality Satisfaction. Yogyakarta: Andy. 